\title{
Sperm retrieval from patients with nonmosaic Klinefelter's syndrome by semen cytology examination
}

\author{
Y.-T. Jiang ${ }^{1}$, Y. Dong ${ }^{1}$, X.-W. Yu ${ }^{1}$, R.-C. Du ${ }^{1,2}$, L.-L. Li ${ }^{1,2}$, H.-G. Zhang ${ }^{1}$ \\ and R.-Z. Liu ${ }^{1}$ \\ ${ }^{1}$ Center for Reproductive Medicine, Center for Prenatal Diagnosis, \\ The First Hospital, Jilin University, Changchun, China \\ ${ }^{2}$ Department of Cell Biology, \\ Norman Bethune College of Medicine, Jilin University, Changchun, China \\ Corresponding author: R.-Z. Liu \\ E-mail:1rz410@126.com
}

Genet. Mol. Res. 13 (1): 1848-1854 (2014)

Received January 3, 2013

Accepted September 3, 2013

Published March 17, 2014

DOI http://dx.doi.org/10.4238/2014.March.17.12

\begin{abstract}
Successful sperm retrieval from ejaculates of nonmosaic Klinefelter's syndrome (KS) patients by using semen cytology examination was described in this report. The clinical parameters of KS patients with sperm compared to patients without sperm were described. One hundred and fifty-one patients were proven to suffer from KS by chromosomal analysis using G-banding. Spermatozoa were obtained from 10 patients $(10 / 151,6.6 \%)$ using semen analysis. After semen cytology examination, 32 patients (32/151, 21.2\%) were found to have sperm or germ cell in their ejaculate. The patients with successful sperm retrieval were significantly younger ( $27.1 \pm 3.7$ years) than the patients for whom sperm retrieval failed ( $28.9 \pm 4.2$ years). The mean serum testosterone level and the mean T/LH ratio of KS patients with successful sperm retrieval were significantly higher in men with sperm than in men without sperm (testosterone: $3.2 \pm 2.1 \mathrm{ng} / \mathrm{mL}$ vs 2.7 $\pm 1.5 \mathrm{ng} / \mathrm{mL}$; T/LH ratio: $0.2 \pm 0.3$ vs $0.1 \pm 0.1$ ). In conclusion, semen
\end{abstract}


cytology examination should be performed to identify sperm and germ cells in the ejaculate of KS patients if no sperm can be detected by traditional semen analysis. The serum testosterone level and T/LH ratio revealed an association between impaired Leydig cell function and impaired spermatogenesis in KS males. KS patients should receive earlier diagnosis and treatment.

Key words: Klinefelter's syndrome; Semen cytology examination; Clinical characterization; Spermatogenic failure

\section{INTRODUCTION}

Klinefelter's syndrome (KS) is characterized by the presence of $\geq 1$ extra X chromosomes. The extra $\mathrm{X}$ chromosome is usually acquired through paternal nondisjunction, and more often results from errors involving maternal meiosis I, meiosis II, or post-zygotic mitosis (Lanfranco et al., 2004). KS is a relatively common condition, afflicting approximately 1 in 600 males. It is the most frequent genetic cause of human infertility, occurring in $11 \%$ of azoospermic men and 4\% of infertile men (Van Assche et al., 1996). Phenotypically, the KS male is characterized by small firm testes, hypergonadotropic hypogonadism, gynecomastia, eunuchoid body proportions, testicular azoospermia, high levels of gonadotropins [folliclestimulating hormone (FSH) and luteinizing hormone ( $\mathrm{LH})$ ], and low to normal levels of testosterone (T) (Lanfranco et al., 2004). In a small number of patients with KS, spermatozoa can be observed in the ejaculate, although the majority of patients are azoospermic (Selice et al., 2010). However, the presence of intratesticular residual foci of spermatogenesis was reported in azoospermic patients with KS (Foresta et al., 1999).

In cases of KS, testicular sperm extraction followed by intracytoplasmic sperm injection enables azoospermic patients to father a child (Vernaeve et al., 2004; Yarali et al., 2009). However, testicular biopsy is an invasive procedure potentially leading to complications such as hematoma, inflammation, fibrosis, and even permanent devascularization and possible androgen deficiency, especially for the small firm testes of KS patients (Schill et al., 2003). Semen cytology detects sperm from the analysis of morphological characteristics, as well as the number of germ cells, form, and proportion, of start of infertility to "cause positioning", providing the basis for clinical treatment (Sardi-Segovia et al., 2011). The present study aimed to evaluate sperm recovery in ejaculate of nonmosaic KS patients with semen cytology examination, and to describe clinical characteristics of KS patients with sperm and without sperm.

\section{MATERIAL AND METHODS}

\section{Patients}

From 2005 to 2011, 151 patients with azoospermia and severe oligozoospermia were diagnosed with nonmosaic Klinefelter's syndrome by chromosomal analysis using G-banding techniques at the Center for Reproductive Medicine of the First Hospital of Jilin University. All patients were presented with questionnaires that included medical history, sexual function, 
family sterility, and history of exposure to harmful substances. Meanwhile, a physical examination was conducted to determine, e.g., age, height, weight, and testis volume. Appropriate voluntary written consents were obtained from the patients and their families. This study was approved by the Chinese Association of Humanitarianism and Ethics.

\section{Chromosome analysis}

Karyotype analysis was performed on peripheral blood lymphocytes by G-banding. Peripheral blood lymphocytes were cultured for $72 \mathrm{~h}$, and G-banding of metaphase chromosomes was performed by hypotension, fixation, trypsinization, and Giemsa staining. At least 30 cells at the metaphase were analyzed from each patient. Chromosomal abnormalities were described according to the International System for Human Cytogenetic Nomenclature (ISCN 2009).

\section{Semen analysis and semen cytology examination}

Semen analysis was performed according to the procedures recommended by the World Health Organization guideline (World Health Organization, 1999). If no sperm was found, semen cytology examination was conducted by sedimenting semen samples through centrifugation, followed by washing with phosphate-buffered saline, $\mathrm{pH} 7.2,3$ times and then spreading the washed semen on glass slides and allowing the spread semen to air-dry. Hematoxylin-eosin staining was performed on the specimen after fixing with $95 \%$ alcohol. The cells were examined under high magnification using a 40X light microscope, and the spermatogenic status was classified according to the Meng system (Meng et al., 2000).

\section{Hormone analysis}

The plasma FSH, LH, and T levels were measured with an electrochemiluminescence immunoassay (Elecsys ${ }^{\circledR} 2010$ Chemistry Analyzer; Roche Diagnostics, Mannheim, Germany). Normal reference ranges for $\mathrm{FSH}, \mathrm{LH}$, and T were $0.8-15 \mathrm{mIU} / \mathrm{mL}, 1.7-8.6 \mathrm{mIU} / \mathrm{mL}$, and 3.2-15.6 $\mathrm{ng} / \mathrm{mL}$, respectively.

\section{Statistical analysis}

All of the data were analyzed using SPSS version 17.0 for Windows (SPSS, Chicago, IL, USA). The chi-square test ( $\chi^{2}$ test) was used to calculate the difference in sperm retrieval rate of the 3 methods. Parametric variables were compared by independent sample $t$-tests, and normally distributed metric variables were compared by the Mann-Whitney U-test. The results are reported as means \pm standard deviation. $\mathrm{P}<0.05$ was considered to be statistically significant.

\section{RESULTS}

Of the 151 nonmosaic KS patients, sperm was observed in the ejaculate of 10 cases (6.6\%) after conventional semen analysis; 6 cases with sperm concentrations ranging from 0.39 to $11.53 \times 10^{6} / \mathrm{mL}$ and 4 cases after centrifugation (2-9 sperms) were included. No 
sperm was observed after centrifugation of 141 cases. After semen cytology examination, 22 cases $(14.6 \%)$ contained sperm or germ cells. One hundred and nineteen cases $(78.8 \%)$ had neither sperm nor germ cells. The sperm recovery rate after semen cytology examination was significantly higher than in semen analysis $(\mathrm{P}<0.01)$ (Table 1$)$.

Table 1. Results of sperm retrieval for nonmosaic KS patients by using semen analysis and semen cytology
examination.
\begin{tabular}{lccc}
\hline Methods & Total No. of cases & No. with sperm retrieved & SRR $(\%)$ \\
\hline A & 151 & 10 & $6.6^{*}$ \\
A+B & 151 & 32 & 21.2 \\
\hline SRR = sperm retrieval rate; A $=$ semen analysis; B = semen cytology examination. *P $<0.01$ compared to A+B.
\end{tabular}

The semen cytology examination results of 22 nonmosaic KS patients with sperm or germ cells are shown in Table 2. We found only a few sperm and germ cells in the ejaculate, and more than $90 \%$ of these cells were Sertoli cells.

The clinical characteristics of the KS patients with sperm and without sperm are as follows. The mean age of the patients with sperm was $27.1 \pm 3.7$ years (range $=21-35$ years), which was younger than the mean age of the patients without sperm of $28.9 \pm 4.2$ years (range $=23-42$ years $)(\mathrm{P}<0.05)$. Comparison of the serum FSH, LH, and testicular volume of patients with and without sperm did not show any statistical difference (Table 2). The mean serum T level was $3.2 \pm 2.1 \mathrm{ng} / \mathrm{mL}$ in men with sperm and $2.7 \pm 1.5 \mathrm{ng} / \mathrm{mL}$ in men without sperm $(\mathrm{P}<0.05)$ (Table 2). The mean ratio of T and LH was $0.2 \pm 0.3$ in men with sperm and $0.1 \pm 0.1$ in men without sperm $(\mathrm{P}<0.01)$ (Table 3$)$.

\begin{tabular}{|c|c|c|c|c|c|c|}
\hline \multirow[t]{2}{*}{ No. } & \multicolumn{6}{|c|}{ Semen cytology examination } \\
\hline & $\begin{array}{c}\text { Spermatogonia } \\
(\%)\end{array}$ & $\begin{array}{c}\text { Primary spermatocyte } \\
(\%)\end{array}$ & $\begin{array}{c}\text { Secondary spermatocyte } \\
(\%)\end{array}$ & $\begin{array}{c}\text { Spermatid } \\
(\%)\end{array}$ & $\begin{array}{c}\text { Spermatozoa } \\
(\%)\end{array}$ & $\begin{array}{l}\text { Sertoli cell } \\
\text { (\%) }\end{array}$ \\
\hline 121 & 1 & 4 & 1 & 23 & 2 & 69 \\
\hline 126 & 0 & 3 & 0 & 2 & 0 & 95 \\
\hline 129 & 0 & 0 & 0 & 0 & 1 & 99 \\
\hline 133 & 0 & 0 & 0 & 0 & 1 & 99 \\
\hline 176 & 0 & 0 & 0 & 0 & 1 & 99 \\
\hline 180 & 0 & 0 & 0 & 0 & 2 & 98 \\
\hline 210 & 0 & 0 & 0 & 0 & 1 & 99 \\
\hline 217 & 0 & 0 & 0 & 0 & 5 & 95 \\
\hline 255 & 0 & 0 & 0 & 0 & 5 & 95 \\
\hline 265 & 0 & 0 & 0 & 0 & 2 & 98 \\
\hline 273 & 0 & 0 & 0 & 0 & 3 & 97 \\
\hline 283 & 0 & 0 & 0 & 0 & 3 & 97 \\
\hline 303 & 0 & 0 & 0 & 0 & 3 & 97 \\
\hline 307 & 0 & 0 & 0 & 0 & 1 & 99 \\
\hline 309 & 0 & 0 & 0 & 0 & 1 & 99 \\
\hline 341 & 0 & 1 & 0 & 0 & 0 & 99 \\
\hline 375 & 0 & 0 & 0 & 0 & 3 & 97 \\
\hline 450 & 0 & 3 & 0 & 5 & 2 & 90 \\
\hline 500 & 0 & 2 & 0 & 0 & 0 & 98 \\
\hline 518 & 0 & 0 & 0 & 1 & 2 & 97 \\
\hline 762 & 0 & 0 & 2 & 2 & 10 & 86 \\
\hline 768 & 0 & 2 & 0 & 0 & 0 & 98 \\
\hline
\end{tabular}




\begin{tabular}{|c|c|c|}
\hline Characteristics & $\begin{array}{l}\text { KS male with sperm or germ cell } \\
\qquad(\mathrm{N}=32)\end{array}$ & $\begin{array}{l}\text { KS male without sperm } \\
(\mathrm{N}=119)\end{array}$ \\
\hline Age (years) & $27.1 \pm 3.7^{*}$ & $28.9 \pm 4.2$ \\
\hline \multicolumn{3}{|c|}{ Testicular volume (mL) } \\
\hline Left testis & $4.5 \pm 3.4$ & $3.3 \pm 2.0$ \\
\hline Right testis & $4.2 \pm 3.2$ & $3.6 \pm 2.1$ \\
\hline FSH $(\mathrm{mIU} / \mathrm{mL})$ & $31.8 \pm 14.4$ & $36.2 \pm 15.3$ \\
\hline $\mathrm{LH}(\mathrm{mIU} / \mathrm{mL})$ & $21.5 \pm 9.8$ & $25.9 \pm 11.2$ \\
\hline $\mathrm{T}(\mathrm{ng} / \mathrm{mL})$ & $3.2 \pm 2.1^{*}$ & $2.7 \pm 1.5$ \\
\hline $\mathrm{T} / \mathrm{LH}$ & $0.2 \pm 0.3^{\#}$ & $0.1 \pm 0.1$ \\
\hline
\end{tabular}

\section{DISCUSSION}

KS patients are typically azoospermic, and in the classic form of KS, spermatozoa are rarely detected in the ejaculate (Paulsen and Plymate, 1992). In a previous study, of $131 \mathrm{KS}$ males, only $8.4 \%$ had spermatozoa in their ejaculate (Lanfranco et al., 2004). We found that $6.6 \%$ of the patients had sperm in their ejaculate after conventional semen analysis, which was similar to what was observed in the former study. However, detection of spermatozoa and germ cells in the ejaculate increased to $21.2 \%$ after semen cytology examination. Therefore, semen cytology should be applied for male infertility diagnosis when the ejaculate specimens do not appear to contain sperm after centrifugation. Semen cytology examination provides an objective test to determine the degree of testicular function injury.

To the best of our knowledge, most KS patients are suffering from severe spermatogenic failure (Friedler et al., 2001). Degeneration of the seminiferous tubules of 47,XXY males is a frequent and well-studied phenomenon, although some tubules with spermatogenesis may be present in adults (Aksglaede et al., 2006). Studies on meiosis concluded that XXY cells are unable to complete the meiotic processes leading to mature spermatozoa (Blanco et al., 2001; Hall et al., 2006). XXY cells cannot efficiently align during meiosis, and unsynapsed chromosomes would disturb the meiotic checkpoint and trigger apoptosis at the pachytene spermatocyte stage (Aksglaede et al., 2006). Apoptosis could contribute to the excessive germ cell demise in males with 47,XXY (Print and Loveland, 2000). Germ cells rarely escape the checkpoint and complete meiosis. In our study, semen cytology examination results of 22 cases of nonmosaic KS patients with sperm or germ cells suggested that residual fertility is possible. Thus far, fertility preservation strategies in KS males aim to preserve spermatozoa or spermatogonia before germ cell depletion occurs (Van Saen et al., 2012).

KS patients are characterized by hypergonadotropic hypogonadism as evidenced by low to low-normal levels of T and high FSH and LH levels. In $65-85 \%$ of adult KS patients, serum $\mathrm{T}$ concentrations are below normal, but some KS patients may show levels that are within the normal range (Lanfranco et al., 2004). In this study, we found that the serum FSH, serum $\mathrm{LH}$, and testicular volume did not show any statistical difference between the 2 groups. The strong correlations of $\mathrm{T}$ and $\mathrm{T} / \mathrm{LH}$ to sperm recovery suggested an association between impaired Leydig cell function and impaired spermatogenesis in KS males. However, the exact mechanism of the androgen deficiency is unknown, and the degree of Leydig cell dysfunction varies (Holm et al., 2003). 
Increased male age is strongly associated with a decline in male spermatogenesis. Some studies have described that age is a limiting factor for successful sperm retrieval in nonmosaic KS males and suggested that earlier infertility assessment and testicular sperm extraction in men with KS might play a critical role in their treatment (Wikstrom et al., 2004; Emre et al., 2006). Wikstrom et al. (2004) found that only $50 \%$ of the boys with KS had germ cells in their testes, indicating a severely impaired fertility potential even in the peripubertal period. Therefore, a potential strategy for infertility in patients with KS is cryopreservation of ejaculated spermatozoa or testicular tissue early in the patients' adolescence (Sousa et al., 2002; Ichioka et al., 2006). Our present study partially supported that age may affect sperm recovery from KS patients. In China, diagnosis of KS in childhood is typically delayed. Most KS patients are not diagnosed until marriage or after marriage. In our study, KS patients with complaints of male infertility lasting 1-12 years came to our reproductive center. Therefore, we suggest that KS patients should achieve earlier diagnosis and treatment. This study highlighted the importance of earlier consultation and assessment to determine the etiology of sterility.

In conclusion, sperm retrieval from nonmosaic KS patients was highly increased by semen cytology examination. The serum testosterone level and T/LH ratio revealed an association between impaired Leydig cell function and impaired spermatogenesis in KS males, and age influenced spermatogenesis in KS males.

\section{ACKNOWLEDGMENTS}

We are grateful to all patients and donors of blood samples. We express our sincere gratitude to all the staff at the Andrology Laboratory for their excellent work. Research supported by the National Population and Family Planning Commission of China (\#2011-GJKJS-07).

\section{REFERENCES}

Aksglaede L, Wikstrom AM, Rajpert-De ME, Dunkel L, et al. (2006). Natural history of seminiferous tubule degeneration in Klinefelter syndrome. Hum. Reprod. Update 12: 39-48.

Blanco J, Egozcue J and Vidal F (2001). Meiotic behaviour of the sex chromosomes in three patients with sex chromosome anomalies (47,XXY, mosaic 46,XY/47,XXY and 47,XYY) assessed by fluorescence in-situ hybridization. Hum. Reprod. 16: 887-892.

Emre BM, Erden HF, Kaplancan T, Ciray N, et al. (2006). Aging may adversely affect testicular sperm recovery in patients with Klinefelter syndrome. Urology 68: 1082-1086.

Foresta C, Galeazzi C, Bettella A, Marin P, et al. (1999). Analysis of meiosis in intratesticular germ cells from subjects affected by classic Klinefelter's syndrome. J. Clin. Endocrinol. Metab. 84: 3807-3810.

Friedler S, Raziel A, Strassburger D, Schachter M, et al. (2001). Outcome of ICSI using fresh and cryopreserved-thawed testicular spermatozoa in patients with non-mosaic Klinefelter's syndrome. Hum. Reprod. 16: 2616-2620.

Hall H, Hunt P and Hassold T (2006). Meiosis and sex chromosome aneuploidy: how meiotic errors cause aneuploidy; how aneuploidy causes meiotic errors. Curr. Opin. Genet. Dev. 16: 323-329.

Holm M, Rajpert-De ME, Andersson AM and Skakkebaek NE (2003). Leydig cell micronodules are a common finding in testicular biopsies from men with impaired spermatogenesis and are associated with decreased testosterone/LH ratio. J. Pathol. 199: 378-386.

Ichioka K, Utsunomiya N, Kohei N, Ueda N, et al. (2006). Adult onset of declining spermatogenesis in a man with nonmosaic Klinefelter's syndrome. Fertil. Steril. 85: 1511-1512.

Lanfranco F, Kamischke A, Zitzmann M and Nieschlag E (2004). Klinefelter's syndrome. Lancet 364: 273-283.

Meng MV, Cha I, Ljung BM and Turek PJ (2000). Relationship between classic histological pattern and sperm findings on fine needle aspiration map in infertile men. Hum. Reprod. 15: 1973-1977.

Paulsen CA and Plymate SR (1992). Klinefelter's Syndrome. In: The Genetic Basis of Common Diseases (King RA, Rotter JI and Motulsky AG, eds.). Oxford University Press, Oxford, 876-894. 
Print CG and Loveland KL (2000). Germ cell suicide: new insights into apoptosis during spermatogenesis. Bioessays 22: 423-430.

Sardi-Segovia LM, Rocher AE, Pugliese MN, Chenlo P, et al. (2011). Prognostic value of germ cells in the ejaculate: a case study. Biotech. Histochem. 86: 232-241.

Schill T, Bals-Pratsch M, Kupker W, Sandmann J, et al. (2003). Clinical and endocrine follow-up of patients after testicular sperm extraction. Fertil. Steril. 79: 281-286.

Selice R, Di Mambro A, Garolla A, Ficarra V, et al. (2010). Spermatogenesis in Klinefelter syndrome. J. Endocrinol. Invest. 33: 789-793.

Sousa M, Cremades N, Alves C, Silva J, et al. (2002). Developmental potential of human spermatogenic cells co-cultured with Sertoli cells. Hum. Reprod. 17: 161-172.

Van Assche E, Bonduelle M, Tournaye H, Joris H, et al. (1996). Cytogenetics of infertile men. Hum. Reprod. 11: 1-26.

Van Saen D, Tournaye H and Goossens E (2012). Presence of spermatogonia in 47,XXY men with no spermatozoa recovered after testicular sperm extraction. Fertil. Steril. 97: 319-323.

Vernaeve V, Staessen C, Verheyen G, Van Steirteghem A, et al. (2004). Can biological or clinical parameters predict testicular sperm recovery in 47,XXY Klinefelter's syndrome patients? Hum. Reprod. 19: 1135-1139.

Wikstrom AM, Raivio T, Hadziselimovic F, Wikstrom S, et al. (2004). Klinefelter syndrome in adolescence: onset of puberty is associated with accelerated germ cell depletion. J. Clin. Endocrinol. Metab. 89: 2263-2270.

World Health Organization (1999). WHO Laboratory Manual for the Examination of Human Semen and Sperm - Cervical Mucus Interaction. 4th edn. University Press, Cambridge.

Yarali H, Polat M, Bozdag G, Gunel M, et al. (2009). TESE-ICSI in patients with non-mosaic Klinefelter syndrome: a comparative study. Reprod. Biomed. Online 18: 756-760. 